\title{
䯣液循環動態と春䯣疾患画像診断の進歩 \\ 一MRI Time-SLIP 法による観察一 \\ Visualization of Cerebrospinal Fluid Dynamics in \\ Normal and Spinal Pathophysiological Conditions \\ Using Time Spatial Spin Labeling Inversion \\ Pulse-MRI

\author{
山田晋也 \\ *1 東芝林間病院脳神経外科 \\ $* 2$ 東芝林間病院水頭症・脳脊髄液センター
}

Key words :

cerebrospinal fluid dynamics $\mathrm{MRI}$

Time-SLIP

syringomyelia

Spinal Surgery 31 (1) 20-27, 2017

\begin{abstract}
Prior to the recent development of the time-spatial spin labeling inversion pulse (Time-SLIP) technique, an innovating imaging method, no method allowed direct tracing of cerebrospinal fluid (CSF) dynamics under physiological and pathophysiological conditions, without disturbing the environment of the central nervous system. Time-SLIP allows the direct visualization of CSF motion using magnetic resonance imaging (MRI), permitting CSF dynamics to be depicted during a certain time frame. CSF dynamics, which are visualized using Time-SLIP, have been found to differ markedly from those describing classical CSF circulation theory in medical textbooks. Thus, Time-SLIP has allowed research on CSF dynamics to advance to the next stage, and provides a more accurate understanding of normal spinal CSF physiology and its alterations in pathophysiological states. The observation of CSF dynamics using Time-SLIP should improve diagnostic accuracy, permitting the identification of new etiological factors in a variety of diseases, and promoting the development of new therapeutic approaches.
\end{abstract}

\section{緒 言}

現在の髄液循環説が提唱されてから 100 年が経過す る る $^{1 \sim 4)}$ 新しい䯣液の可視化手法である MRI Time-spatial labeling inversion pulse（SLIP）法が開発されて直接 髄液ダイナミクスを観察することが可能となってきて得 られた知見では, 現在教科書に記述されている髄液の循 環生理から想像される流れとはかなりかけ離れた動きで ある. MRI Time-SLIP 法を簡単に紹介し, それによって 観察された髄液ダイナミクスについて解説し, 脊髄疾患 への応用を示す。

\section{今までの髄液動態の観察}

脊椎くも膜下腔に存在する髄液は, その総量の半分を 占めるといわれるにもかかわらず5), 頭蓋内での髄液ダ
イナミクスの研究に比べ観察は少ない，中枢神経である 脳と脊髄は髄液に浸された状態で存在し，さらに頭蓋骨 と脊椎に囲まれているため, 半閉鎖腔として取り扱われ る、それゆえに，外部から針を刺し造影剤を注入するこ とは生理的な動態が乱されることになるので，正常ある いは病的な状態のときの実際の髄液動態が観察されな い. 古くは放射性同位元素を使ったRI 脳槽造影, 造影剂 注入によるミエログラフィー, さらにそれを CT で撮像 したCT脳槽造影がそれに当たる。造影剤を注入すると 注入量分の体積変化が生じ, 髄液圧の変化も生じ得る.

さらに造影剤は, 髄液の主たる成分である水とは分子量 も粘稠度も異なるために, 髄液動態を正確に追従して捉 えることができない．この問題点の認識があるにもかか わらず，現在の教科書的な髄液ダイナミクスは，おもに

*1 東芝林間病院脳神経外科 / $7252-0385$ 相模原市南区上鶴間 7-9-1〔連絡先：山田晋也〕

Address reprint requests to : Shinya Yamada, M.D., Ph.D., Department of Neurosurgery, Toshiba Rinkan Hospital, 7-9-1 Kamitsuruma, Minami-ku, Sagamihara-shi, Kanagawa 252-0385, Japan

*2 東芝林間病院水頭症・脳脊䯣液センター /Department of Hydrocephalus and Cerebrospinal Fluid Research Center 
それら外因性トレーサー検査を使用した観察から得られ た概念である ${ }^{6,7)}$. MRI を使用した髄液観察では，外部か ら造影剤を注入する必要がないために生理的な状態で観 察がヒトで可能となったことは画期的なことであったの で, MRI phase contrast 法（PC 法）によってヒトの䯋液 動態生理に関して多くの研究がされた ${ }^{8 \sim 10)}$. しかしなが ら, MRI PC 法は S/Nの問題からごく最近まで, 心電図, あるいは脈波をトリガーとして同期をとり収集されたシ グナルの加算平均をとる必要があるために, 当然の結果 とはいえるが，心拍，あるいは脈拍の変化に同期した動 画像が得られてくる。しかし, 腰椎穿刺のときに髄液の 拍動を直接肉眼で観察すると, 拍動には心拍に同期する 細かい動きと呼吸に連動する大きな拍動があることは, 臨床医であれば誰でも観察している．PC 法で得られる 結果はとても誤差が大きいことが知られているが，これ は呼吸による生理的な髄液の拍動を無視した結果である ことは容易に推測できる。このPC法を使用して, 当初 期待されたほどの臨床的な応用が得られなかった大きな 原因が，ここにあるといえる。呼吸と心拍という 2 つあ る髄液拍動のドライビングフォースを 1 つのものとして 加算平均化してしまったことで, PC 法では正確な髄液 の拍動描出ができなかったといえる。ここで紹介する Time-SLIP 法によって, 呼吸に連動する髄液動態が初め て画像として可視化されると, PC 法に扔いてもこの問 題が再認識され, ごく最近ではあるが加算平均をとらな い real time PC 法が開発されつつあり, 呼吸の髄液拍動 に及ぼす影響が重要視されてきた ${ }^{11)}$. RI 脳槽造影, CT 脳槽造影では造影剤の動きを観察することで髄液の流れ を可視化することが可能である，と考えられていたが, 髄液そのものをMRIにより内因性のトレーサーとして 使用することができる Time-SLIP 法の観察からは, 造影 剂の動きを観察することでは髄液動態の拍動を追従でき ず，注入部位と観察部位の空間の連続性を描出するにす ぎないことが理解されてきた。 ミエログラフィー施行 時, 体位を変化させることで造影剤を望む位置に移動さ せられることを経験する。つまり，上位頚椎を観察した いときには頭部を低い位置にした状態で造影剤を上行さ せることからもわかるように，造影剂は髄液より相対的 に重い，そして，現在の教科書に述べられる脊椎くも膜 下腔の髄液の流れは，そのような造影剂のふるまいの観 察から推測されたものといえる。

Time-SLIP 法以前には，ヒトに扔いて生理的条件を乱 さず脊髄くも膜下腔の髄液の動態を直接トレースし, 可 視化した技術はない。

\section{Time-SLIP 法による髄液観察}

Time-SLIP 法は arterial spin labeling あるいは spatial spin labeling と呼ばれる手法をモディファイし, 髄液観 察に最適化したものである ${ }^{12)}$. Time-SLIP 法では初めに 撮像面全体に 1 回目の inversion recovery pulse(IR pulse) を印加して背景画像全体を反転させる（非選択的 IR pulse と呼ばれ, 背景画面は全体に黒く描出される). 直 後に観察を行いたい䯣液の部分に带状に再度 IR pulse (選択的 IR pulse と呼ばれる) を印加すると, 初めのIR pulse で一度黒く反転された髄液が再反転されて, 再反 転された部分のみが白く描出される, 再反転され白く描 出された髄液が一定時間の間に黒い背景の部分に動く （移動する）ので，時間を执いて撮像を行う〔time interval（TI）と称される】 と, 背景と再反転された髄液のコ ントラストから髄液の移動が可視化される。この撮像か ら画像描出までに single shotで撮像されるので, PC 法 のような加算平均を必要としない. すなわち, 画像とし てみえたものがその観察時間内に動いた髄液ということ ができる。印加した IR pulse は, 1.5 T MRIでは 8 秒ほど でその効果が消失するが，実際の観察には印加された髄 液とバックグラウンドの間でコントラストが残っている ことが前提条件であるので, 非選択的 IR pulse を印加し てから 5 6秒までが現実的な観察時間である. 印加直後 1 秒以内も, シグナルの回復を待つ関係から現状では観 察されない. 結論として 1 亿秒ほどの間がこの方法での 髄液動態が可視化される時間である。外因性の造影剤を 注入する場合は，一度造影剂を髄液腔に注入すると造影 剂が完全に䯣液から消失するのに数日を要するが, MRI Time-SLIP法ではパルスの物理特性として約 8 秒で完全 にシグナルが消失して，もとの状態に戻るために，同一 日に何度でも繰り返しの検査することが可能である。す なわち, 同じ部位を繰り返し撮像して観察された髄液動 態の再現性を確認することや，一検查内でさまざまな箇 所の髄液動態を観察できることが Time-SLIP 法の特徵 ということができ，この方法の大きなアドバンテージで ある. Time-SLIP 法は髄液そのものを内因性のトレー サーとして使用することができるトレーサースタディと いうことができる。詳細はほかに讓るが，完全に連続し て撮像することが可能な steady state free precession （SSFP）法によるTime-SLIP 法も開発され，呼吸による 髄液動態など, さらに自然な状態での髄液の観察も可能 となっている ${ }^{13)}$.

\section{髄液循環生理}

脊髄くも膜下腔の髄液動態を考えるときに, 頭蓋内を 
含めた髄液循環生理全体の把握は必須であるのでTimeSLIP 法でみられた所見と教科書にある記述との矛盾を 紹介する，最近の教科書では，いわゆる古典的な髄液循 環生理についての記述に対し, Time-SLIP 法の観察など から近年ではその正当性が疑問視されているという注釈 がつくようになってきている ${ }^{14,15)}$. 前述したように, 古 典的な髄液循環説の概念は, 20 世紀はじめにCushing と Weedによって提唱されたといえる に存在する脈絡叢から産生され, 第四脳室からマジャン ディー孔，ルシュカ孔を通り，〈も膜下腔に流出する. 最終的に髄液は, 大脳円蓋部のくも膜下腔を通過し, 上 矢状洞周辺のくも膜顆粒で吸収される。髄液は産生部位 から吸収部位に向かって川の流れのように一方向に流れ るとされる，脈絡叢の血管は血液脳関門を欠く血管であ るが，髄液とのインターフェースである脈絡叢上皮には tight junction が存在し, 髄液は血液から active transport によって産生されるとされる。一方, 吸収はくも膜顆粒 に执いて passive transportによって行われ，髄液圧が上 昇すると吸収量が増加する比例関係にあるとされる。こ の髄液吸収路がくも膜顆粒であるとする見解は, Key ら ${ }^{17)}$ の髄液色素注入後の解剖学的観察をもとにしている が, 同部位における髄液吸収のメカニズムの詳細は, い まだに明らかにされたとはいいがたい.くも膜下腔に第 四脳室から流出した髄液の一部は, 脊椎くも膜下腔を下 行したのち再度上行して脳底槽に達し, 直接脳室から流 入した髄液と合流し前頭葉と側頭葉の間隙に存在するシ ルビウス裂のくも膜下腔, 一部は左右の大脳半球間裂の くも膜下腔を通過し, 大脳円蓋部を経てくも膜顆粒に到 達すると説明される，特に現在の脊椎くも膜下腔におけ る髄液の流れについての教科書的記述はDi Chiroによる 精力的な RI 脳槽造影の結果から推測されたものといえ $3^{6,7,18)}$. そこでは脊椎の歯状勒带の腹側と背側のくも膜 下腔では流れる方向が違い, 脊髄より背側は下行（尾 側), 腹側は上行 (頭側) する同時に異なる 2 方向に向か う流れが脊椎くも膜下腔の中で存在すると報告した。 ま た，座位の状態でヒトの側脳室に注入された放射線標識 をしたヒトアルブミン (radio labeled human albumin : RISA）は数分で脳室からくも膜下腔に排出され，10２0 分で頚部脊椎くも膜下腔に到達し, その後 $30 \sim 40$ 分で胸 椎くも膜下腔全体に，60９０分で腰椎くも膜下腔を満た すことを観察した. Di Chiroらは，小さな分子量の卜 レーサーTc-pertechnetateを使用すると, 注入した局所 で吸収されてしまうことも同時に報告している18)。さら には, 大半の髄液は脳組織の毛細血管のどこからでも産 生吸収されるが一部 (5 分の 1 3 分の 1) はバルクフロー
（流れ）としてくも膜顆粒から吸収されると考えると記述 している7). Cushing の髄液循環説提唱から 50 年を過ぎ た時点であるが，脳の毛細血管を介した髄液産生吸収が 現在の主流の考えであるとまで記述されている77.

近年の古典的髄液循環説に対する数々の矛盾はまさに この点で, 血液脳関門の概念から, 脳毛細血管は水その ものも通過させないという印象を与えたからであると推 察する。放射線標識した水は静脈内に投与すると, single pass (1 回循環) で $80 \%$ 以上が脳組織に移行すること がすでに 1960 年代には報告されている ${ }^{19)}$ 。髄液の $99 \%$ は水であるので, 水の移動を髄液の産生, 吸収と考える のか，あるいは髄液中に投入された高分子量のトレー サーの動きを髄液の産生, 吸収とするのかという点が, 実際の髄液循環生理の解明に必要な論点であるといえ $3^{20)}$. 当然, 髄液の産生吸収という生理的動態は水の移 動に注目するべきであることはいうまでもない. TimeSLIP 法は髄液（水）自体をラベルすることができること から，分子量や粘稠度などは髄液そのものであり，実際 の髄液拍動を直接可視化することが可能な, 現時点で唯 一無二の方法であるといえる。詳細はほかに譲るが, 髄 液は局所で拍動をみせるのみで，いわゆる古典的な髄液 循環である産生部位（脈絡叢）から吸収部位（くも膜顆 粒）に向けての一方向性の流れ，バルクフローは観察さ れない21,22)。髄液の産生吸収は脳毛細血管を介して局所 的に行われ ${ }^{23 \sim 27)}$, 血液脳関門を通過できない高分子物 質はリンパ系へドレナージされると考える28 37).

\section{䯣液拍動のドライビングフォース}

Real time Time-SLIP 法を用いることで，心拍あるい は呼吸の同期をとらずに髄液動態の連続撮像が可能と なっている ${ }^{13)}$.この方法で脊椎くも膜下腔の髄液動態を 観察すると, 腰椎穿刺時に髄液を肉眼で観察したときと 同様に，心拍と同期する小さな振幅をみせる拍動と，大 きな振幅で呼吸と同期する拍動を観察することができ る. 2 つのドライビングフォースが不規則に重なるため, 生理的髄液の動きは完全な反復性をもたない。この脊椎 くも膜下腔の髄液動態から定量的な速度解析や拍動幅解 析を行うためには，今まで使用されてきた PC 法による 加算平均化されたデー夕はそぐわず real time の連続撮 像が必須となることが容易に理解できる。呼吸や心拍の みならず，髄液は体の動きで大きく攪拌される ${ }^{21,22,26)}$, さらに体位によっても䯣液拍動は大きく変化する ${ }^{12)}$. 今 までは, 静止状態での髄液の観察しか行われてこなかっ たが，実際に生活している状態では体動，動きが一番大 きな髄液を動かすドライビングフォースであろう． 

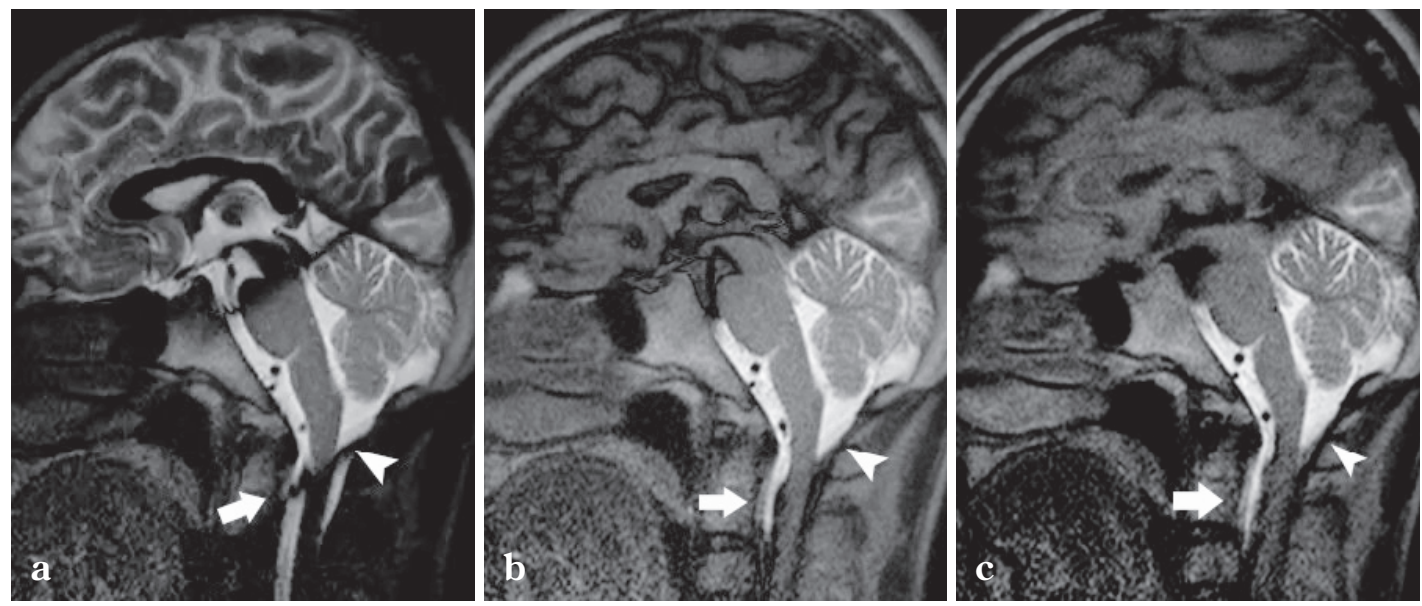

Fig. 1 正常脳. 矢状断面像 Time-SLIP 法 頭蓋䅡椎移行部での観察

a : time interval (TI) $1,500 \mathrm{msec}, \mathbf{b}:$ TI $2,100 \mathrm{msec}, \mathbf{c}:$ TI 3,300 msec

橋前槽から脊髄腹側くも膜下腔にかけてラベルされた髄液の拍動が観察される (矢印)。同部位はくも膜下腔の髄液拍 動の中でも最も大きな拍動を観察する部位である，大孔部の脊髄背側くも膜下腔には大きな髄液の拍動は認めない (矢頭).

\section{正常脊椎くも膜下腔での髄液動態}

MRI の上で仰臥位の状態での脊椎くも膜下腔の髄液 動態を観察すると, 脊髄腹側くも膜下腔の髄液が拍動す る様子が観察される。一方で, 春髄背側くも膜下腔の髄 液は動きを認めない，頝椎，胸椎，腰椎どの部位のくも 膜下腔でも同様な所見である。ところが同じ被験者を腹 臥位で撮像すると，脊髄背側くも膜下腔の髄液が拍動を はじめる，腹臥位になると脊髄は脊椎間内で前方に移動 し，脊髄背側のくも膜下腔にスペースが生まれることに よって, 脊髄脊側のくも膜下腔の髄液拍動が出現す $3^{12)}$. 多くの正常例で澒椎, 胸椎, 腰椎のどの部位でも 脊髄腹側の髄液が優位に拍動するが, 脊柱の弯曲が強 く, 特に胸椎で前方に脊髄が位置する例では, 背側脊髄 くも膜下腔に空間が生じ正常仰臥位においても背側春髄 くも膜下腔の髄液拍動が観察されることがある。すなわ ち, 髄液はその時点で一番抵抗の少ない（空間のある） 部分を動くことが理解される. 春椎くも膜下腔全体でみ ると, 髄液拍動は脊椎管の中央付近の拍動が大きく, 末 端「cul-de-sac」に近づくにつれ，拍動幅が減弱する。 MRI で観察されるものは圧波ではなく拍動流（pulsatility）であるので, 円柱の端に近づくにつれ拍動が少なく なることになる。すなわち, 同じ被験者に抢ける同一生 理環境下の脊䯣くも膜下腔に执いても, 観察場所によっ て拍動の大きさは異なることが理解される。このこと は, 髄液拍動を定量的な解析で比較検討することが容易 ではないことを示唆している。 このTime-SLIP法による 観察は, 現在の教科書に記述されている脊椎くも膜下腔 の髄液の流れの想像図とはかけ離れている。現在の概念
のもとになったDi Chiro の RIによる観察では，前述の ように脊柱管くも膜下腔内で歯状勒带の腹側, 背側で逆 方向に向かう流れがあるとされ，同時に体位や，その変 換によってこれらの動きが変化することはなかったとも 記述されている ${ }^{18)}$ 。これらの観察での解釈の誤りの大部 分は，髄液より重い外因性のトレーサーを使用したこと による pitfall であると推察される。

\section{正常の頭蓋顤椎移行部における髄液拍動}

橋前槽から脊椎腹側くも膜下腔にかけての髄液の拍動 は, くも膜下腔で最も大きなものである. 対して, 小脑 中部の下部, 脊髄背側には通常は大きな髄液拍動を認め ない $($ Fig. 1)，大きな脳槽が存在するとき以外は，同部 位の頭側は小脳中部で遮られる。矢状断面の撮像ではほ とんどの拍動は脊髄腹側くも膜下腔に観察される.

\section{病的状態での骾液ダイナミクスの変化 1 脊髄空洞症}

脊髄疾患で, 最も髄液生理動態が密接にかかわってく る病態である，髄液の病的な振る舞いが空洞症の発生， あるいは進行に深くかかわり, 髄液動態の異常を外科的 に改善することが治療となる。しかし，肝心な脊髄空洞 症の成因は諸説あるが，いまだに解明されたとはいえな い38). 現在でもよく議論にのぼる説を簡単に紹介する。

Gardner theory : 第四脳室から直接脊髄中心管に髄液 圧が加わり中心管が拡大するとする説で，第四脳室出口 の閉塞を合併することが多いとされる，空洞を拡大する 圧力の起源は脈絡叢が想定され, 圧は water-hammer 


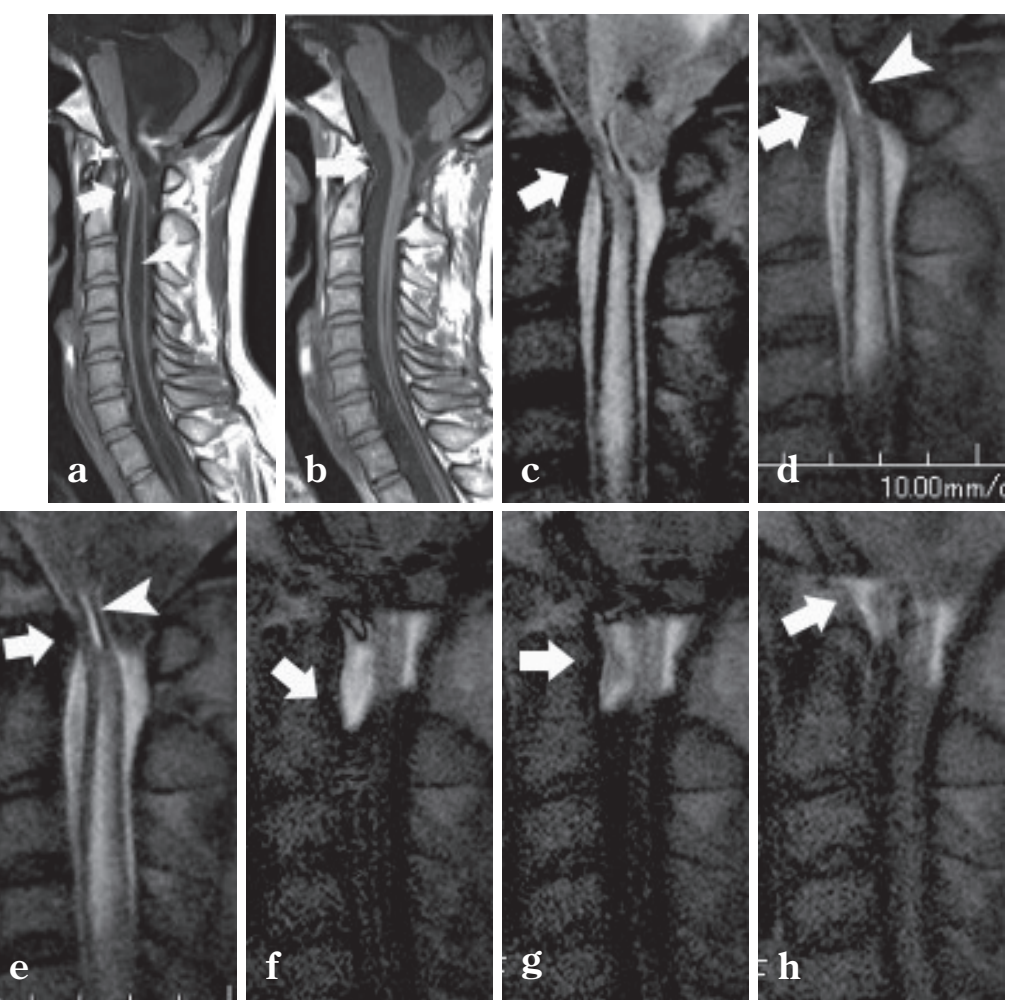

Fig. 2 水頭症合併脊髄空洞症

$\mathbf{a}$ : 術前 $\mathrm{T} 1$ 矢状断面像. 小脳虫部の下垂を認め頭蓋頚椎移行部に狭窄を認める. 同 部位のくも膜下腔は圧排され虚脱している (矢印)。春髄空洞症を認める.

b : 術後 $\mathrm{T} 1$ 矢状断面像. 大孔減圧術を施行. 脳幹, 春䯣は後方に移動し脳幹, 脊䯣 前方にスペースが生まれていることが観察される (矢印)。脊髄空洞症は虚脱消 失している.

$\mathbf{c} \sim \mathbf{e}$ : 術前矢状断面像. Time-SLIP 画像〔c : time interval (TI) $1,700 \mathrm{msec}, \mathbf{d}:$ TI $2,300 \mathrm{msec}, \mathbf{e}:$ TI $3,500 \mathrm{msec}]$

頭蓋䅡椎移行部に非選択的 IR pulse を印加し髄液動態を観察する. 頭蓋澒椎移行部 の狭窄のため脊椎くも膜下腔の髄液と頭蓋内くも膜下腔の髄液の交通が消失してい る様子が描出される (矢印)。さらに, 空洞内の髄液が中心管の上方に伸びており, いわゆるWilliams 説の slosh effect を観察している可能性がある (矢頭). $\mathbf{f} \sim \mathbf{h}$ : 術後矢状断面像, Time-SLIP 画像（f : TI 1,700 msec, g : TI 3,500 $\mathrm{msec}, \mathbf{h}$ ： TI 4,300 msec).

春髄前方に生じたくも膜下腔の髄液に拍動が観察され, 脊椎くも膜下腔の髄液と頭 蓋内くも膜下腔の髄液が交通されたことが観察される.

effect（水撃作用: 水圧管内の水流を急に締め切ったとき に, 水の慣性で管内に衝撃と高水圧が発生する現象）で 伝搬され，空洞症が発生するとされる，後頭蓋窩の拡大 による減圧術に加え obex を plugging する手術を Gardner 手術と呼ぶ.

Williams theory : 脊髄くも膜下腔の圧力と頭蓋内くも 膜下腔圧力格差によって脊髄空洞症が発生するとする説 である．頭蓋澒椎移行部のくも膜下腔に狭窄が存在する ときに，咳をするなどの胸腹腔内圧の上昇が脊髄硬膜外 静脈叢の拡張を誘発し, 結果として脊椎くも膜下腔圧の 上昇を生じる。すると, 脊椎くも膜下腔の髄液は, 頭蓋 内くも膜下腔に移動し, 頭蓋内くも膜下腔の圧力が上昇
する，正常の状態ではこの後，すぐに同じ量の髄液が摇 り戻すように頭蓋内くも膜下腔から脊柱くも膜下腔に還 流されるわけであるが, 頭蓋䅡椎移行部に病変がある状 態では, 脊椎くも膜下腔に髄液が戻る際に小脳虫部が大 孔にone way valveのように嵌まり込む形となって, 脊椎 くも膜下腔へ髄液が還流されない (ball valve effect)。す ると, 髄液が還流されなかった脊椎くも膜下腔の脳脊髄 圧は陰圧となり, 結果, 春髄中心管の圧力が陰圧となる. そこへ頭蓋内髄液が中心管から流れ込む形になり春髄空 洞症が発生する (suck effect)。一度, 宜髄空洞症が形成 されると, 脊柱管くも膜下腔の脊髄硬膜外静脈叢の容積 変化によってつくり出される圧力は, 髄液で満たされた 

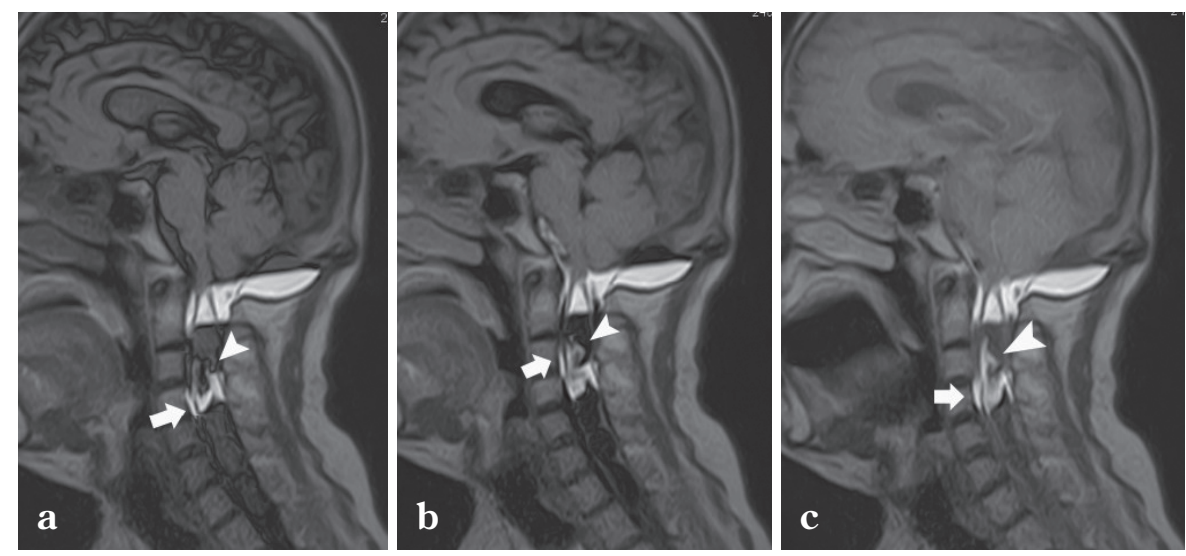

Fig. 3 脊髄空洞症, 矢状断面像, Time-SLIP 画像 a : time interval (TI) $1,700 \mathrm{msec}, \quad \mathbf{b}:$ TI $2,100 \mathrm{msec}, \mathbf{c}:$ TI $3,100 \mathrm{msec}, \mathbf{d}:$ TI $3,700 \mathrm{msec}$.

くも膜下腔の髄液の動き（矢印）と春髄空洞内の髄液の動き （矢頭）は連動していない。〈も膜下腔の䯣液の上下方向への 拍動と, 隔壁を乗り越えるように移動する空洞内髄液の動き が観察される.

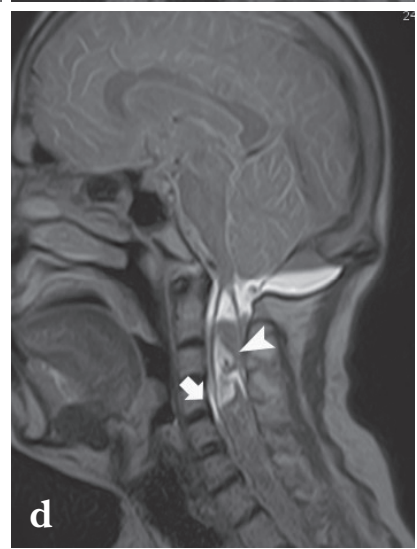

脊髄空洞内に圧波として伝搬し空洞症を進行させる (slosh effect)。ときに延髄あるいはさらに頭側に伸びて いく脊髄空洞症, 延髄空洞症の発生機序がこれで説明さ れる。手術の方法としては, 頭蓋䅡椎移行部での狭窄の 改善を目的とし, 後頭蓋窩の拡大による減圧術が手術と して用いられる。

Ball and Dayan 説 : 非交通性空洞症ではくも膜下腔の 髄液が血管周囲腔（いわゆるVirchow-Robin 腔）から侵 入して空洞を形成するとする説である ${ }^{39)}$ ，特に，髄液が 脊髄細胞外腔を通過して空洞に侵入する際のドライビン グフォースを, 大脳の拍動に伴う容積変化に起因した小 脳虫部のピストン状下垂に言及した説が Oldfield's theory とされる ${ }^{40)}$. Ball and Dayan 説は非常に限られた数 の剖検例で, 髄液への色素注入を行うと血管周囲腔を経 由して空洞に色素が侵入したことを観察して考察された ものであるが，正常脊髄でも脳組織間液と髄液の血管周 囲腔を介した自由な交通は，現在ではよく知られてい る。この両説はいずれもくも膜下腔血管周囲腔から脊髄 空洞に髄液が細胞外液を経由して侵入するという考え方 が基本となるが, 脊髄の外側から圧勾配によって空洞に 髄液が侵入するとなると, 空洞は外側から圧迫され虚脱 するはずであり，空洞形成の原因をうまく説明できない。

\section{Time-SLIP 法による脊髄空洞症の観察}

正常脳では認める橋前槽から脊髄くも膜下腔に連続す る髄液拍動が, くも膜下腔髄液の拍動の中で一番大きい (Fig. 1). 頭蓋䅡椎移行部の狭窄に伴う脊髄空洞症例で は $($ Fig. 2 a)，橋前槽から脊髄腹側くも膜下腔に連続す る髄液拍動が消失する $($ Fig. 2 c e ) , 空洞内の髄液が上 方に伸びており，いわゆるWilliams 説の slosh effectを 観察している可能性がある (矢頭)，大孔の拡大術によっ て，脊髄小脳は後方に移動することができるようにな り, 結果として脊椎腹側くも膜下腔にスペースが生ま れ，術後すぐに空洞の消失が観察される $($ Fig. 2 b). 春 髄くも膜下腔の髄液は, 頭蓋くも膜下腔へと自由に拍動 することができるようになる (Fig. $2 \mathbf{f} \sim \mathbf{h})$ ，大孔の拡大 による減圧術で改善される髄液動態は, 大孔における春 髄背面, 小脳虫部下面の髄液腔を直接修復しているので はなく, 春髄前面のくも膜下腔の拍動であることが観察 される。この症例に扔ける髄液動態の障害部位は, 頭蓋 頝椎移行部であるといえるが, 髄液動態の観察からは諸 説存在する脊髄空洞症の発生成因説のいずれにも言及で きないものの, 前述したようにslosh effectの結果を観察 できている可能性がある（Fig. 2 e, f). Time-SLIP 法で は，髄液の動きのディテールのみならず空洞内の髄液の 
詳細な動きも同時に観察される．Fig. 3 の脊髄空洞症例 では，空洞内には隔壁が存在し，それを乗り越えるよう に移動する空洞内髄液が描出されている. 脊椎くも膜下 腔の髄液と空洞内の髄液の動きは連動していないことも 観察される (Fig. 3). 空洞内の髄液の動きと脊椎くも膜 下腔の髄液の動きを同時に観察することで，交通性の有 無, ひいては個々の症例の成因について考察することが できる。

\section{脊髄囊胞性疾患}

脊髄囊胞性疾患の囊胞内髄液の動きは, くも膜下腔の 髄液の動きと連動しないことから異なる空間であること が容易に観察される。

\section{脊椎管狭窄}

狭窄部位に一致して, 䯣液拍動が障害される。狭窄の 程度も観察可能であり，侵襲的なミエログラフィーを行 わなくとも容易に自然な状態での経過観察ができる。ま た，体位を変化させての観察も，MRI ボアの大きさが許 す限り可能であり, 体位の変化による脊椎アライメント の変化に伴う髄液動態を非侵襲的に描出することが可能 であると考える。

\section{おわりに}

非侵襲的な髄液のトレーシング技術である MRI Time-SLIP 法が, 髄液生理の既存の概念に多くの新しい 知見をもたらしたといえる。過去の多くの観察の結果自 体は正しいといえるが，䯣液は循環するという Cushing 以来の bulk flow theoryによる先入観から, 結果の解釈 に大きな問題があったことが理解される。生体において 重要な基礎的な生理が現在でも理解されていないという 事実はきわめて珍しいことであり，あらためて新しい概 念で髄液生理を考えることが未解決の病気やヒトの生理 の解明に役に立ち, 診断, 治療法につながることが期待 される。

\section{文 献}

1) Cushing $\mathrm{H}:$ Studies on the Cerebro-Spinal Fluid : I. Introduction.J Med Res $3 \mathbf{1}:$ 1-19, 1914

2) Weed LH : Studies on cerebro-spinal fluid. No. IV : the dual source of cerebro-spinal fluid. J Med Res $31: 93-118,1914$

3) Weed LH : Studies on cerebro-spinal fluid. No. III : the pathways of escape from the subarachnoid spaces with particular reference to the arachnoid villi. J Med Res $31: 51-91,1914$

4) Weed LH : Studies on cerebro-spinal fluid. No. II : the theories of drainage of cerebro-spinal fluid with an analysis of the methods of investigation. J Med Res $31: 21-49,1914$

5) Bull J : Radiation dose in isotope encephalography. Lancet 2 :
871, 1968

6) Di Chiro G : Observations on the circulation of the cerebrospinal fluid. Acta Radiol Diagn (Stockh) 5 : 988-1002, 1966

7) Dichiro G : Movement of the Cerebrospinal Fluid in Human Beings. Nature 204:290-291, 1964

8) Bradley WG Jr : Phase-contrast imaging documents CSF in motion. Diagn Imaging (San Franc) 13:116-119, 1991

9) Feinberg DA, Mark AS : Human brain motion and cerebrospinal fluid circulation demonstrated with MR velocity imaging. Radiology 163: 793-799, 1987

10) Quencer RM, Post MJ, Hinks RS : Cine MR in the evaluation of normal and abnormal CSF flow : intracranial and intraspinal studies. Neuroradiology $32: 371-391,1990$

11) Dreha-Kulaczewski S, Joseph AA, Merboldt KD, et al : Inspiration is the major regulator of human CSF flow. J Neurosci 35 : 2485-2491, 2015

12) Yamada S, Miyazaki M, Kanazawa $H$, et al : Visualization of cerebrospinal fluid movement with spin labeling at MR imaging : preliminary results in normal and pathophysiologic conditions. Radiology 249:644-652, 2008

13) Yamada S, Miyazaki M, Yamashita $Y$, et al : Influence of respiration on cerebrospinal fluid movement using magnetic resonance spin labeling. Fluids Barriers CNS $\quad \mathbf{1 0}: 36,2013$

14）太田富雄 (編): 脳神経外科 (第 12 版)。京都, 金芳堂, 2016, pp2024-2025

15）太田富雄 (編): 脳神経外科 (第 12 版). 京都, 金芳堂, 2016, pp2034-2035

16) Cushing $\mathrm{H}$ : The Third Circulation and Its Channels. (Cameron Lecture). Lancet $2: 851-857,1925$

17) Key A, Retzius $G$ : Studien in der Anatomie des Nervensystems und des Bindegewebes. Stockholm, Samson \& Willin, 1875

18) Chiro GD, Hammock MK, Bleyer WA : Spinal descent of cerebrospinal fluid in man. Neurology $26: 1-8,1976$

19) Crone $\mathrm{C}:$ The Permeability of Capillaries in Various Organs as Determined by Use of the 'Indicator Diffusion' Method. Acta Physiol Scand $58: 292-305,1963$

20）宮嶋雅一, 山田晋也：髄液循環動態を再考する。老年精医誌 $26:$ 1155-1162, 2017

21) Yamada $S$ : Cerebrospinal fluid physiology : visualization of cerebrospinal fluid dynamics using the magnetic resonance imaging Time-Spatial Inversion Pulse method. Croat Med J $55: 337-346,2014$

22) Yamada S, Kelly E : Cerebrospinal Fluid Dynamics and the Pathophysiology of Hydrocephalus : New Concepts. Semin Ultrasound CT MR $37: 84-91,2016$

23) Klarica M, Oreskovic D : Enigma of cerebrospinal fluid dynamics. Croat Med J 55 : 287-290, 2014

24) Oreskovic D, Klarica $M: A$ new look at cerebrospinal fluid movement. Fluids Barriers CNS $11: 16,2014$

25) Oreskovic D, Klarica M, Vukic M : Does the secretion and circulation of the cerebrospinal fluid really exist? Med Hypotheses $56: 622-624,2001$

26）山田晋也：脳脊髄液の生理 : 脳脊髄液のダイナミクス. 医学 物理 $32: 148-154,2012$

27) Igarashi $\mathrm{H}$, Tsujita $\mathrm{M}$, Kwee IL, et al : Water influx into cerebrospinal fluid is primarily controlled by aquaporin -4 , not by aquaporin-1 : 17O JJVCPE MRI study in knockout mice. Neuroreport $25: 39-43,2014$

28) Cserr HF, Cooper DN, Suri PK, et al : Efflux of radiolabeled polyethylene glycols and albumin from rat brain. Am J Physiol 240 : F319-328, 1981

29) Shibata M, Yamada S, Kumar SR, et al: Clearance of Alzheimer's 
amyloid-ss (1-40) peptide from brain by LDL receptor-related protein-1 at the blood-brain barrier. J Clin Invest $106: 1489$ 1499, 2000

30) Yamada S, DePasquale M, Patlak CS, et al : Albumin outflow into deep cervical lymph from different regions of rabbit brain. Am J Physiol 261 : H1197-1204, 1991

31) Yamada S, Shibata M, Scadeng M, et al : MRI tracer study of the cerebrospinal fluid drainage pathway in normal and hydrocephalic guinea pig brain. Tokai J Exp Clin Med $\quad 30: 21-29,2005$

32) Zlokovic BV, Yamada S, Holtzman D, et al : Clearance of amyloid beta-peptide from brain : transport or metabolism? Nat Med $\quad 6: 718-719,2000$

33) Johnston M, Zakharov A, Koh L, et al : Subarachnoid injection of Microfil reveals connections between cerebrospinal fluid and nasal lymphatics in the non-human primate. Neuropathol Appl Neurobiol 31:632-640, 2005

34) Weller RO, Kida S, Zhang ET : Pathways of fluid drainage from the brain-morphological aspects and immunological significance in rat and man. Brain Pathol 2 : 277-284, 1992
35) Bading JR, Yamada S, Mackic JB, et al : Brain clearance of Alzheimer's amyloid-beta40 in the squirrel monkey : a SPECT study in a primate model of cerebral amyloid angiopathy. $J$ Drug Target $10: 359-368,2002$

36) Iliff JJ, Nedergaard M : Is there a cerebral lymphatic system? Stroke $44:$ S93-95, 2013

37) Iliff JJ, Wang M, Liao Y, et al : A paravascular pathway facilitates CSF flow through the brain parenchyma and the clearance of interstitial solutes, including amyloid beta. Sci Transl Med 4 : 147-111, 2012

38) Rai SK, Rai PS : Volume change theory for syringomyelia : A new perspective. Asian J Neurosurg $10: 245-251,2015$

39) Ball MJ, Dayan AD : Pathogenesis of syringomyelia. Lancet 2: 799-801, 1972

40) Oldfield EH, Muraszko K, Shawker TH, et al : Pathophysiology of syringomyelia associated with Chiari I malformation of the cerebellar tonsils. Implications for diagnosis and treatment. $J$ Neurosurg $80: 3-15,1994$ 